SECTION 1. Theoretical research in mathematics.

Mamaraimov Mukhidin Tashbulatovich

candidate of pedagogical Sciences, Director

Shymkent humanitarian-technical College, Shymkent,

Republic of Kazakhstan.

\title{
THEORY AND METHODS OF TEACHING TOPOLOGY ELEMENTS IN ORGANIZATIONS, REALIZING PROFESSIONAL TRAINING PROGRAMMES OF TECHNICAL AND VOCATIONAL EDUCATION
}

In the scientific article is a review, the issues of training, as well as the goals, approaches and prerequisites teaching topology, and in particular, its elements.

Keywords: methods of training, topological material, training programmes

\section{ТЕОРИЯ И МЕТОДИКА ОБУЧЕНИЯ ЭЛЕМЕНТАМ ТОПОЛОГИИ В ОРГАНИЗАЦИЯХ, РЕАЛИЗУЮЩИЕ ПРОФЕССИОНАЛЬНЫЕ УЧЕБНЫЕ ПРОГРАММЫ ТЕХНИЧЕСКОГО И ПРОФЕССИОНАЛЬНОГО ОБРАЗОВАНИЯ}

В научной статье дан обзор, рассмотрены вопросы обучения, а также цели, подходы и предпосылки преподавания топологии, и в особенности, её элементов.

Ключевые слова: методика обучения, топологический материал, учебные программы.

В курсе математики организациях технического и профессионального образования, студенты встречаются с такими терминами, связанными с топологией как "вне", "внутри", "граница", но эти термины зачастую "привязаны" к какой-либо конкретной геометрической фигуре и в дальнейшем "не работают". Втопологических структурах с точки зрения математики отражаются представления об окрестности, пределе, непрерывности, об области, как части пространства или плоскости, обладающей свойством непрерывности к которым приводит само окружающее нас пространство. Именно эти понятия будут активно использоваться в дальнейшем при определении геометрических фигур и отношений между ними.

Итак, роль топологических знаний в математическом образовании студентов определяется: 
- их основополагающим значением для геометрических знаний студентов (все пространства, изучаемые в геометрии - это топологические многообразия с обогащенной структурой):

- первичностью топологической структуры в формировании математического мышления студентов;

- развивающими функциями топологических задач, которые предполагают развитие исследовательских навыков, навыков самоконтроля и креативности студентов:

- их большим воспитательным потенциалом, проявляющимся, прежде всего, в эстетическом воспитании студентов, формировании их научного мировоззрения, а также многих ценных личностных качеств (самостоятельность, активность, трудолюбие и так далее).

Как было уже отмечено выше, необходимость выделения топологической линии в организациях технического и профессионального образования курса математики обуславливается рядом предпосылок:

1. Психологическая. Топологическая структура является первичной по отношению к проективной и метрической подструктурам. Следовательно, и обучение должно строиться согласно развитию математического мышления студентов.

2. Мировоззренческая. В настоящее время геометрию понимают как теорию структур, более богатых, чем структура топологического многообразия.

То есть все пространства, изучаемые в геометрии, прежде всего топологические пространства.

Исходя из изложенных предпосылок и общих целей обучения математике, можно сформулируем цели изучения элементов топологии:

\section{Общеобразовательные цели.}

Овладение системой математических знаний, умений и навыков, дающей представление о предмете топологии, еe языке и символике,топологическом моделировании, топологических методах и приемах связанных с ними, о развитии топологии.

\section{Воспитательные цели.}

Формирование мировоззрения студентов, формирование логической и эвристической составляющей мышления, формирование алгоритмической культуры, приобщение к творческой деятельности, воспитание нравственности, культуры общения, самостоятельности, активности, эстетическое воспитание студентов, воспитание трудолюбия.

\section{Практические цели.}

Формирование умения строить топологические модели простейших реальных объектов и явлений, исследовать их по заданным моделям, конструировать приложения моделям, ознакомление с ролью топологии.

В настоящее время всё больше методистов организации технического и профессионального образования приходят к 
необходимости введения элементов топологии в курс геометрии. На данный момент существуют следующие подходы:

1. Включение в систематический курс математики, теории графов и её приложений

2. Некоторые задачи топологического характера включаются в основное содержание курса математики с пометкой "для учеников, увлекающихся математикой".

3. Топологический материал предлагается для внеклассной работы

4. Отдельные темы предлагаются для студентов технических специальностей с углублённым изучением математики

5. Некоторые вопросы топологии предлагаются для внеклассной работы в старших курсах.

А также этими вопросами занимались А.М. Абрамов, Х.Ж. Танеев, Г.В. Дорофеев, Л.В. Занков, Н.Б. Истомина-Кастровская, В.С. Леднев, В.М. Монахов, З.И. Слепкань, Н.Ф. Талызина

Работы ученых-математиков таких как Р. Декарт, Н.И. Лобачевский, М.В. Остроградский, А. Пуанкаре, А.Д. Александров, А.Н. Колмогоров, Г. Фройденталь, Д. Пойа, В.Г. Болтянский, Б.В. Гнеденко, Л.Д. Кудрявцев, А. Я. Хинчин, Туканаев Тұрар Дәуренбекович, Наурызбаев Руслан Жумабайович, Умирбаев У.У, и др. раскрывают значение математического образования для общекультурного развития личности.

Труды А.М. Абрамова, Х.Ж. Танеева, Г.В. Дорофеева, Л.В. Занкова, Н.Б. Истомина-Кастровской, В.С. Леднева, В.М. Монахова, З.И. Слепкана, Н.Ф. Талызиной и др направленные на анализ основных направления и путей развития современного математического образования с ориентацией на развивающую функцию обучения имеет громадные значение для включение в систематический курс математики, теории графов и её приложений.

Книга Утиной Риммы Кажихановны изданное в 2011 году в городе Костанай, имеет колесальное значение для успешнего освоения программы курса «Дифференциальной геометрии и топологии».

Для построения содержания материала по топологии для студентов технических специальностей, организации технического и профессионального образования предполагаю проанализировать принципы отбора, структурирования, а также критерии отбора и характеристики содержания учебного материала, выделяемые различными авторами. А принципы отбора и построения содержания материала по топологии нужно применить с трудов методистов как Дорофеев Г.В., Ибраев А., Подходова Н.С. Саранцев Г.И., Тестов В.А., Сангалова М.Е.

\section{Список литературы:}


1. Дорофеев Г.В. О принципах отбора содержания школьного математического образования// Математика в школе. 1990. - № 6-С. 2-5.

2. Ибраев А. К вопросу о преподавании элементов топологии в старших классах средней школы. Дис. . канд. пед. наук. -М., 1971.

3. Подходова Н.С. Теоретические основы построения курса геометрии 16 классов: Дис. докт. пед. наук. С.-П. 1999.

4. Саранцев Г.И. Методология методики обучения математике. -Саранск: Тип. "Крас. Окт.", 2001.- 144 с.

5. Тестов В.А. Математические структуры как научно-методическая основа построения математических курсов в системе непрерывного образования (школа вуз). Дис. . д-ра пед. наук. - Вологда, 1998.404 с.

6. Сангалова М.Е. Принципы отбора содержания внеклассной работы по топологии // Математика и информатика: наука и образование. Межвузовский сборник научных трудов. Ежегодник. Выпуск 1. Омск.

8. Утина Р. К. Дифференциалдық геометрия және топология. Оқулық. Костанай 2011. 